\title{
Geo-political and Geo-economic Dynamics of the Region in Developing the Sea-based Economy of the IOR Countries
}

\author{
Kanwar Muhammad Javed Iqbal, Baber Bilal Haider
}

\begin{abstract}
The geo-politics and geo-economics of the Indian Ocean Region (IOR) littoral are interconnected to each-other with a large scale of Afro-Asian population and a tremendous maritime economic potential. Welfare interests of the populations of IOR littoral states demand tapping of the Sea-based economic potential, but the geopolitical dynamics of the region are not conducive due to diverse dimensions of multiplayers in the region and gradual Sino-Asian power shift, where philosophy of enhanced cooperation for peace and sustainability is highly needed. The addition of Belt and Road Initiative (BRI) has provided new avenues to harness the true potential and uplift the poverty by improving existing socioeconomic ties. The BRI has many challenges, and its opportunities can be exploited by China, Pakistan and Iran, through an extra efforts on diplomatic front. Based on qualitative research and content analysis method, this paper aims to analyse the various aspects of the geo-politics and geo-economics of the IOR viz-a-viz Sea-based economic potential and rationalizes the need of enhanced cooperation for peace and sustainability in order to promote socioeconomic uplift and prosperity across Afro-Asian region.
\end{abstract}

Keywords: Indian Ocean, Geo-political, Geo-economic, IOR Littoral, Afro-Asian region, Sea-based economy, Welfare interests, SLOC, CPEC, OBOR, Chahbahar Port, Gwadar Port, enhanced cooperation, socio-economic uplift.

Kanwar Muhammad Javed Iqbal is a Former Research Fellow at Sustainable Development Policy Institute, Islamabad-Pakistan, and Research Fellow at Center for Global \& Strategic Studies, Islamabad - Pakistan reachable at kanwar.javediqbal@gmail.com

Baber Bilal Haider is a PhD Scholar at National Defense University, Islamabad Pakistan, reachable at cdrbaber@yahoo.com 


\section{Introduction}

Indian Ocean is one of the busiest and most important ocean worldwide. Covering an area of $73,556,000 \mathrm{sq} \mathrm{kms}$, this ocean consists of some of the most critical sea lanes and choke points. Indian Ocean region connects three continents (Asia, Africa \& Australia) and two Oceans (Pacific and Atlantic) with each o ther. This means that the security of this region is absolutely vital for economic activities on more than $50 \%$ of the globe. Moreover, the Indian Ocean is the battleground for some of the key sea lanes in the world including Strait of Hormuz and Malacca Strait. Almost 90,000 commercial vessels annually transport 9.84 billion tonnes through Indian Ocean. It's strategic position crossing global trade connecting the major international economic hubs in the AsiaPacific \& Northern Atlantic implies the dominance in the Indian Ocean, which is pivotal to influence the trade of major economies of the world.

The Sea Lines of Communications (SLOCs) in IOR region got more significance in late $90 \mathrm{~s}$, when the forces of globalisation stimulated huge economic growth resulting in enlarged consumption \& competitive trade and generating an increase in oil demand in both developed \& developing countries. The significance of Indian Ocean is beyond comparison because the energy cargoes that flow through this ocean run majority of the world's economies. The 36 million Barrels per day is around $40 \%$ of the global supply of oil \& $64 \%$ of oil trade move through entryways of the Indian Ocean.The most important of these include the Straits of Malacca, Hormuz, \& Bab-el-Mandeb ${ }^{1}$. It's also richly blessed with fishing and aquaculture resources. Mineral resources in the seabed are present in abundant quantities with nodules containing iron, copper, zinc, cobalt, nickel, manganese, silver and gold present. Coastal sediments of Indian Ocean also have sources of zirconium, titanium, zinc, tin, \& copper and various rare earth elements. Indian Ocean is also home to many island countries like, Maldives, Seychelles, Mauritius, Madagascar etc. whose entire

1 Dhruva Jaishankar, "Indian Ocean Region: A Pivot for India's Growth” , BROOKINGS, September 12, (2016). 
economies are dependent on the ecosystem of the waters near them."

The geo-politics and geo-economics of the Indian Ocean Region (IOR) littoral are interconnected to each-other due to large scale of Afro-Asian population, trade \& cultural routes, sea-based economy, coastal tourism and other interests of leading global powers. Welfare interests of the populations of IOR littoral states demand tapping of the Sea-based economic potential, but the geo -political dynamics of the region are not conducive due to diverse dimensions of multiplayers in the region and gradual Sino-Asian power shift, where philosophy of enhanced cooperation for peace and sustainability is highly needed. The addition of Belt and Road Initiative (BRI) has provided new avenues to harness the true potential and uplift the poverty by improving existing socioeconomic ties, but has many challenges.

Based on qualitative research and content analysis method, this paper aims to analyse the various aspects of the geo-politics and geo-economics of the IOR viz-a-viz Sea-based economic potential and rationalizes the need of enhanced cooperation for peace and sustainability in order to promote socio-economic uplift and prosperity across Afro-Asian region.

\section{Outlook of the Geopolitics Of IOR}

Asia has the world's largest human resources and consequently natural markets, consumer markets, development scope, \& connectivity potential. For better connectivity with the world through major channels present in Indian Ocean, it is called strategic cond uit of commerce, which makes foundation for trading systems, that underpins Asia's economic significance. At present, Asia is the centre ground of great power rivalries with Russia \& China being taken as challengers by the U.S and its allies turning the region more competitive than cooperative. Afghanistan presents part of this picture with a devastating war since 17 years with no end in sight.

From Pakistan's perspective, it's important to ally itself with forces of regional progress, and for that it has to alter the region and turn itself into mega trade corridor. For this purpose, Pakistan 
has increasingly realized that its future lies in pursuing the common future of this region including Afghanistan, Central Asian Republics, Iran and China and sometimes with Russia. Furthermore, it also realizes that perpetual hostility with India is not going to serve any purpose and the only way to solving the disputes in this region is through shared vision of prosperity for huge population deprived of the opportunities it deserves to materialize its potential. The biggest and most important player to carve out this constructive picture out of this troubled region is undoubtedly China; let us briefly see roles in the IOR.

\subsection{Chinese Role in IOR}

China's emerging strategy for the maritime affairs in IOR has two interconnected building blocks i.e. a philosophy of a two Ocean's Navy and initiative on the maritime silk route for which an aggressive work is being done by China over the last 10 years or so in order to achieve these two milestones in an influencing manner ${ }^{2}$

China is marching its way to pursue "two-ocean" strategy with a slow and steady mode, thus gradually expanding its maritime operations from Western Pacific and Southern Sea into the IOR. Endorsed since mid-2000s, China's strategy of "Far-Seas Operations" is manifested by its vision of building placement with adequate berthing arrangements in the Indo-Pacific region. This arrangement would address the energy security challenges and imperatives with improved achievement on "far seas protection". This will also provide an extra edge in projection of its naval power. Such a tectonic like transition i.e. shifting a "near sea policy" into a "far sea policy" can be considered a landmark conversion inside the intellectual maritime capacity as was reflected by the Chinese in the recent years. China's naval force posturing is rooted in its evolved ocean-centric strategic thinking. It may be considered an indicator of a bigger game plan with

\footnotetext{
${ }^{2}$ Amy Derr, A. (2015, January 26,). "The Pursuit of Peaceful Expansion: China's Maritime Silk Road of the 21st Century through Offensive Realism and Complex Interdependence," WORDPRESS, January 26, https://myoldresearchpapers.wordpress.com/2015/01/26/the-pursuit-of-peacefulexpansion-chinas-maritime-silk-road-of-the-21st-century-through-offensive-realismand-complex-interdependence/
} 
strong naval presence in the Indian Ocean as manifested by the recent naval events with a shift from eastern to western IOR quadrants, which are observed on an ever increasing scale since 2017.

On February 2017, in the eastern part of the IOR, China fired its cruise missile 3 and its Haikou and Changsha destroyers for the purpose of war readiness through the combated drills, and the exercise was also meant to meet any piracy related challenge with swift response mechanism. Now, sighting of Chinese naval surface ship and submarines is quite often in the eastern Indian Ocean quadrant. This Chinese presence includes surveillance vessels for tracking the tri-lateral Malabar exercises by the US, India and Japan, which were performed in the Bay of Bengal with an apparent intention, against China, to show a level of implicit balance in this maritime zone. At the same time, China's posture was very smart with a mature expression in the form an extended invite to India, in August 2017 through Capt. Liang Tianjun4, for joint efforts towards enhanced maritime safety and security in IOR. In return for ensuring a multi-actors' symbiotic relationship in IOR, China wants to safeguard its interests i.e. peaceful operations for energy/ national security that can be ensured with no-hindrance from the presence of all other states in the region.

On the other hand, India is observed very sensitive for this Chinese presence, as it is considered its strategic backyard by India ${ }^{5}$, with its own ocean claim to an extent thus aspire to have pre-eminence over it. Contrary to it, emergence of Chinese role in the IOR renders an overall maritime encirclement when compared with the Indian land encirclement.

\footnotetext{
${ }^{3}$ David Scott, "Chinese Maritime Strategy for the Indian Ocean," CIMSEC, (November 28, 2017).

4 Deputy Chief of General Office of China's South Sea Fleet

5 Aneja, A, “China Deploys Warships in Indian Ocean," THE HINDU, February 21, 2018.
} 
Another Chinese deployment activity occurred in August 2017 with Chinese naval formation / exercise ${ }^{6}$ in the waters of Western IOR. There was an unprecedented live fire drill in which strikes were made against an assumed enemy's naval surface vessels. Though the assumed "enemy" was kept classified but the overall scenario made it obvious to the intelligentsia of the world that the Indian Navy was the rival in sight, as it was also highlighted in the South China Morning Post where this Chinese drill was mentioned a clear warning for India. However, the Indian concerns were brushed off by the Chinese print media groups ${ }^{7}$. For the purpose of power show, China opened up a "logistics support facility" at Djibouti during September 2017 and also conducted a complete package of military exercises.

\subsection{Chinese Maritime Agenda and the Silk Route}

In October 2017, the 19th Congress of the ruling Party in China was held and led to important strategic decisions. The Congress for the first time, officially wrote the need and continuation of "Belt and Road Initiative (BRI)" into the Party Constitution. The "Belt" refers to overland road across Eurasia including the CPEC, while, the road corresponds to the Silk Route initiative by China; all were started in 2013.It is a first kind of a maritime project consisting geo-economic \& geopolitical outcomes safeguarding maritime interests of China and power considerations significantly. However, in May 2017, an advanced BRI Forum was held in Beijing, attended by eleven IOR states which are part of the Silk Route project; included Bangladesh, Iran, Indonesia (by the President), Australia, Kenya (by the President), Malaysia (by the Prime Minister), Maldives, Singapore, Myanmar, Sri Lanka (by the Prime Minister), and Pakistan (by the Prime Minister). The major emphasis of the forum was maintained on the maritime and overland Silk Route projects.

6 The formation included live show of guided-missile frigate, destroyer and supply vessel along-with a fire drill.

7 Yuandan and Yusha. "India should get used to China's military drills: expert," Global Times, August 27, 2017, http://www.globaltimes.cn/content/ 1063429.shtml 


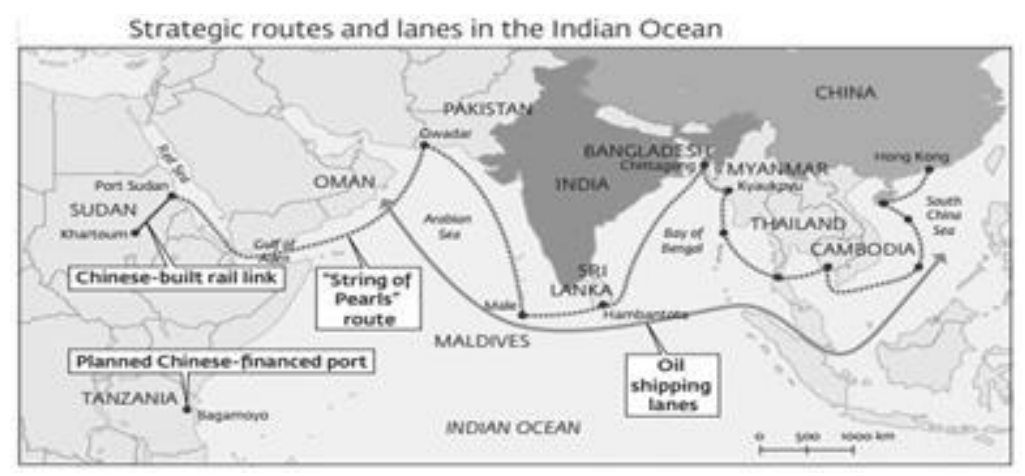

Source: Chinese BRI documents and other material

On 20th June 2017, a white paper was revealed by the China and it was titled "Vision for Maritime Cooperation under the Belt and Road Initiative", and was prepared by the NDR Commission \& SOA - the Oceanic Administration of China prepared this document. It was termed as an absolute and "pragmatic cooperation" including "shelving differences and building consensus for a win-win scenario towards the efforts of upholding the existing international ocean order." However, the document didn't mention the refusal of China to permit the tribunal adjudication of UNCLOS regarding its claim in the waters of Southern China Sea.

The concept of Silk Route's BRI is developed with an excellent vision for interconnected ports \& nodal points stretching across the IOR and beyond. It is very important and has a lot of significance for China's three-fold connectivity in the IOR. Firstly, the infrastructure projects linking in formulation of nodal points and to promote active participation of Chinese enterprises. Secondly, to secure the interest of growing number of Chinese merchant ships; third and the last is to install its naval power in order to safeguard commercial aspects including the shipping business.

The Chinese BRI agenda with the provision of ports in or near the IOR would have a greater likelihood to shift the strategic geopolitical agenda and relocate the geographical features / positions as were outlined in of U.S String of Pearls Framework 2005; and if happens so, it would be an ultimate outcome of the Chinese strategy behind its bigger game play for which it is constructing 
bases as well as services in the IOR and beyond i.e. a chain stretching from Gwadar, Hambantota, Chittagong and Sittwe. However, whole Chinese advancement is very calm and perhaps classified that is why it has always denied the existence of any such policy. But, the situation is pretty clear as it has made continuous efforts during the last decade in order to develop a series ports usage agreements across the IOR and beyond that is why allied facilities are included at Mombassa \& Djibouti.

The year 2017 observed a rapid penetration of China in the IOR ports. In September (2017), China and Myanmar reached to an agreement whereby China got $70 \%$ stakes, for its state owned company CITIC, in the running deep water Kyauk Pyu. This port is strategically located providing a very good entrance to the Myanmar-China O\&G pipeline. Earlier in July 2017, Sri Lanka agreed to a similar agreement with $70 \%$ stakes for Chinese state owned company CMPH in development of port Hambantota with a lease arrangement over 99 year period. Given role to state ow ned companies signifies a deliberate strategy of China's central government.

The Gwadar port located on Pakistan's serene coastline is being considered a precious pearl towards Chinese agenda and strategy in the IOR. Its construction is being done under China's financial assistance for CPEC, and it is owned and administered by another Chinese state owned company COPHC with a lease tenure of 40 years. The strategic significance of Gwadar for China includes energy supplies from the Middle East and the CPEC which is meant to have an improved infrastructure for bilateral connectivity.

The strategic significance of Gwadar \& Kyauk Pyu will certainly help China in addressing its current vulnerability of the Malacca Dilemma; whereby energy imports of China sailing across eastern part of the IOR i.e. Malaccan Strait can potentially be cut off by the India or U.S.A. with their naval presence. 


\subsection{Chahbahar Port}

It is worth mentioning that Iran's development of Chahbahar port, as a strategic port with Indian assistance, on the mouth of Strait of Hormuz has been apparently seen as a rival of Gwadar port in countering the increasing influence and economic be nefits for China and Pakistan in the region. However, China's outlook of the port of Chahbahar is not marred by insecurity. In December 2017, China expressed its interest to Iran to establish a connection between Pakistan's Gwadar port and Iran's south-eastern port of Chabahar. China informed Iran that it was interested in using Chabahar to transit goods from Gwadar to regional and extraregional destination points ${ }^{8}$. The Foreign Minister of Iran, Dr Javad Zarif again visited Pakistan in March 2018 and asked Pakistan to participate in Chahbahar seaport project and its development for linkage with Gwadar Port. He wanted to allay concerns here over Indian involvement at Chahbahar port. ${ }^{9}$

While the Indian tactics of aligning with the US in Afghanistan against the interests of China and Pakistan to integrate the whole region for initiating a new chapter of regional and global prosperity have added a negative tone to the regional development. However, it is a known fact that Gwadar has strong edge over Chahbahar port for its geographic location to rule maritime waters utility and its vicinity with China due to the road connectiviy. Chabahar is not located in the Indian Ocean region, where Indi a's other functional ports: Mumbai, Nava Sheva, Goa, and Kolkata are situated having the shelter of the Indian Navy to protect their maritime operations. The vicinity of Gwadar to Chahbahar port $(72 \mathrm{~km})$ covering a Pakistan Navy dominated area would always continue to a nuisance for India especially after China has gained administrative control of Gwadar since April 2017.

8 China wants link between Gwadar Chabahar ports. https://www.presstv.com/ Detail/2017/12/27/546973/China-wants-link-between-Gwadar-Chabahar-ports. Published: 27th December 2017. Accessed: 20th September 2018.

9 Sayyed, Baqir Sajjad.(2018, March 13). "Iran invites Pakistan to participate in Chahbahar Propject". Dawn.com, Retrieved from https://www.dawn.com/news/ 1394938. 
Moreover, China has already invited India to enter the joint venture of the Maritime Silk Road (MSR) but the Indian side has so far refrained from showing any interest in joining this game changing historic project. The absence of India at the Belt and Road Forum held in Beijing on May 2017 was a clear message of disinterest or perhaps mistrust which is so deeply embedded in the Indian psychology for both Pakistan and China. The official explanation for this Indian boycott was China's linkage of the CPEC to the MSR initiative and since CPEC goes through the disputed area of Jammu \& Kashmir, India wanted to register its dislike for the initiative. Since its inception, India is quite cautious about the whole MSR initiative as this initiative geographically surrounds the India. India perceives that it is another strategy of China to enclose India. However, China has officially denied any such strategy.

The geo-economics of the MSR presents China with interests to acquire, maintain, and defend if needed. And these interests can only be safe guarded through a strong Navy.

\subsection{China's Improving Naval Power}

The Chinese maritime strategy seems to further strengthen and is expected to manifest in China's improvised capability to utilize more powerful assets into the Indian Ocean region. In the $19^{\text {th }}$ Party Congress, a formal resolution approved President Xi Jinping's call to build a powerful \& modernized navy. In 2017, an unprecedented pace of Chinese naval capacity building was observed.

One indicator of this was the unveiling of the Type 055 destroyer in June. Which is Chinese Navy's first 10,000 tons nationally created and domestically built surface warrior. ${ }^{10}$ Chinese official state media (XINHUA) considered this a milestone in refining the nation's navy armament system and building a strong \& modern navy. The Type 055 is the China's first new generation destroyers.

${ }^{10}$ Andrew Tate, A. (2018, July 3). China launches two Type 055 destroyers simultaneou sly in Dalian. Jane's360 [London]. 
Till now, China has not deployed its aircraft carrier in Indian Ocean. It converted an ex-Soviet carrier, the Varyag, installing it into the navy as the Liaoning in 2012. However, it is important to mention that China is already deploying towards the Indian Ocean, where in January 2017 saw the Liaoning leading a warship flotilla into the South China Sea including drills with advanced J15 aircraft making it the first Chinese aircraft carrier deployment into the South China Sea and established a strong policy to showcase maritime power. This projection was partially in context of signifying clear superiority over local rival beneficiaries in the South China Sea and partially to commence matching U.S. aircraft carrier dispositions into waters that China claims as its own. However, the U.S. claims it as international waters, in which it could commence freedom of navigation exercises.

A massive development for Chinese aircraft carrier power projection is the faster construction of its home-made aircraft carrier during 2017. China's first indigenous aircraft carrier Type 001A was launched on April, 2017 at Shanghai with berth exercises conducted at Dalian in October. By 2018, this new aircraft carrier appears to join the Chinese Navy, which is two years earlier than initially expected. It's projected to be placed with the South China Sea fleet thereby reserved for regular distribution into the South China Sea \& IOR. It's expected to feature an electromagnetic launch system. The event creates a strategic acceleration of Chinese efforts for building a blue water navy to ensure its safe key maritime trade routes and to encounter America's dominant position in the Asia Pacific region along with India's position in the IOR.

\subsection{Countervailing Responses}

In response to China's Maritime Silk Road (MSR) initiative, India has started to pursue its own Mausam \& Cotton route projects as an initiative for the Indian Ocean cooperation, deliberately leaving China out of this exercise. India alongside Japan is engaged in promoting the Africa Asia Growth Corridor (AAGC), which also does not include China. American advocacy of the Indo-Pacific Economic Corridor (IPEC) for linking South Asia to South-East Asia has also seen in link with the Indian and 
Japanese proposals. As for the Chinese "two-ocean" naval strategy, the increased deployment in the Indian Ocean has led to India moving rapidly towards trilateral security cooperation with Jap an and the US. Australia also beckons in this regional response to China manifested in recovery of "Quad" discussions between US, Australia, India, \& Japan on $12^{\text {th }}$ Nov,2017. This offset security development comprises the trilateral MALABAR exercises in June 2017 among American, Japanese, and Indian Naval forces in which these exercises in the Bay of Bengal exhibited a move of venues from the Western Pacific into the IOR. Australia is also most likely to join the MALABAR structure within this "Quad" development.

\subsection{Maritime Threats and Pakistan's Role in IOR}

About 95\% of Pakistan's trade is carried out through the ports of Karachi, Port Qasim, and Gwadar with Pasni,Ormara, Jiwani, and Gadani and receiving small number of cargoes. These harbours, especially Karachi, Port Qasim and Gwadar have tremendous significance for Pakistan, landlocked Central Asian States and Afghanistan and now increasingly China in view of the CPEC project. Long serene coastline \& significant harbours provide Pakistan with a strategic location, which is ideal for sea trade and other commercial activities conducted in mostly for eign ships. The role of Pakistan in international navigation, the Gwadar port, and the EEZ is very important for its economic development.

However, the rise of non-conventional threats near coastal areas of Pakistan hamper its economic \& security interests. Ignoring all these impacts will intentionally place Pakistan in an adverse position with land-locked countries to which, Pakistan wants to offer a pathway to IOR. Unless or until these subconventional \& non-traditional threats are resolved, Pakistan wouldn't be able to conquer its national security.

Therefore, it is important to stabilize the economy for acquiring defence modernization and to deal with non-traditional threats. In addition, Pakistan also needs to focus more on naval empowerment of its naval forces for ensuring security at its sea lane, 
international trade, and maritime interests in Indian Ocean region.

These uninterrupted threats of terrorism have transnational apprehensions for diplomatic interests of Pakistan in Indian Ocean region. Possible assaults by radical military factions with the assistance of regional powers opposing CPEC on seaports and coastlines along with dangers of weaponization, human trafficking and drugs smuggling could obstruct global trade activities on coastline of Pakistan.

These serious maritime security threats not only marginalize national security of Pakistan but also other coastal states of the Indian Ocean region. Collective cooperation and comprehensive maritime security strategy can be an effective way to safeguard national \& regional interests. International ships \& ports facilities meant to secure world maritime standards offer the guideline principles for safety and security of ports \& sea lines. Under the se rules \& regulations, a joint intelligence system and a security plan can be shared focussing on maritime security agencies, customs, immigration, police, piracy, narcotics control and related issues.

\section{Geo-Economic Capacity of The Indian Ocean Region}

The world has dramatically changed during past 150 years or so, and with every decade passing by, new technological heights are achieved, and new commercial avenues opened. Advancement in medical technology, pharmaceutical technology, transportation, and communication and literally every other field during the past century, and a half has increased the life expectancy of a child and has resulted in upsurge of population that is unprecedented in human history. According to United Nations report ${ }^{11}$ The current world's population of 7.6 billion is projected to rise up to 8.6 billio $\mathrm{n}$ in the 2030, 9.8 billion in year 2050, and 11.2 billion in the year 2100. Around 83 million people are being added to the world population each year with the rising trend in population size is anticipated to rise further. More than $60 \%$ of this population (about 4.5 billion) lives in Asia. This means that the driving force of world's economy lies in Asia.

11 United Nations report, 21 June, 2017. 
Indian Ocean being the connecting channel for East Asia, South Asia, Australia, Middle East and Africa, bulk of this expected upsurge in trade will be seen in its waters. Apart from the huge oil supplies that move from Gulf to the Far East, major share of the rest of the items that constitute these 11.6 billion tons per annum seaborne trade also go through Indian Ocean. Looking at the world container port volumes by region, $64 \%$ of the trade goes to Asia. This shows the importance of the seaports in our area. Then if you look at the world's ports rankings by volume, 9 out of the top 12 ports are located in China alone. So that indicates the direction of the world economy and signifies the importance of Indian Ocean in general and CPEC and Gwadar in particular for Pakistan.

With the rise of China, India and the newly developing ports in the Indian Ocean region such as Gwadar (Pakistan), Chahbahar (Iran), Kyauk Pyu (Myanmar) etc., along with the additional factor of OBOR and CPEC present a future picture of much higher trade volumes. China's increasing demand for fuel from the Middle East and its pursuit to overcome United States as the large st economy of the world in the coming years, along with factors of demographically younger populations in countries like Pakistan, Afghanistan and India means ever increasing demand for goods. This will be facilitated by enhanced regional connectivity through OBOR projects which aim to transport goods at a faster pace due to shortening of time and distance (major aims of OBOR \& CPEC) will result in tremendous commercial growth and job creation for the people of the not only the IOR region, but also for Central Asia and Europe.

\subsection{OBOR \& CPEC'S Significance for IOR Geo-Economics}

China launched the ambitious, game changing the Belt and Road Initiative (BRI) in 2013, a project which is intended to develop physical infrastructure across sixty-five countries in Asia, Europe, \& Africa. China intends to invest around USD 150 billion in these projects every year till their completion, pledging more than $\$ 900$ billion towards in total. This unprecedented initiative includes building of ports, power houses, bridges, railways and se a routes which will link East Africa and the Mediterranean region with the southern coast of China in two ways. One way is the 'Maritime Silk Road, whereas the other is the Silk Road Econo mic 
Belt. The latter consists of a number of overland corridors, which will connect China to Europe via Central Asia and with Middle East via Pakistan. There are six economic corridors that China is building now, and all of these are interconnected to each other. These are China-Mongolia-Russia Economic Corridor (CMREC), the New Eurasian Land Bridge (NELB); the China-Central \& West Asia Economic Corridor (CCWAEC); the China-Indo-China Peninsula Economic Corridor (CICPEC); the China Pakistan Economic Corridor (CPEC); and the Bangladesh-China-IndiaMyanmar Economic Corridor (BCIMEC). Looking at all of these corridors, CPEC's overarching significance cannot be ignored as it occupies a central position in the whole OBOR project ${ }^{12}$.

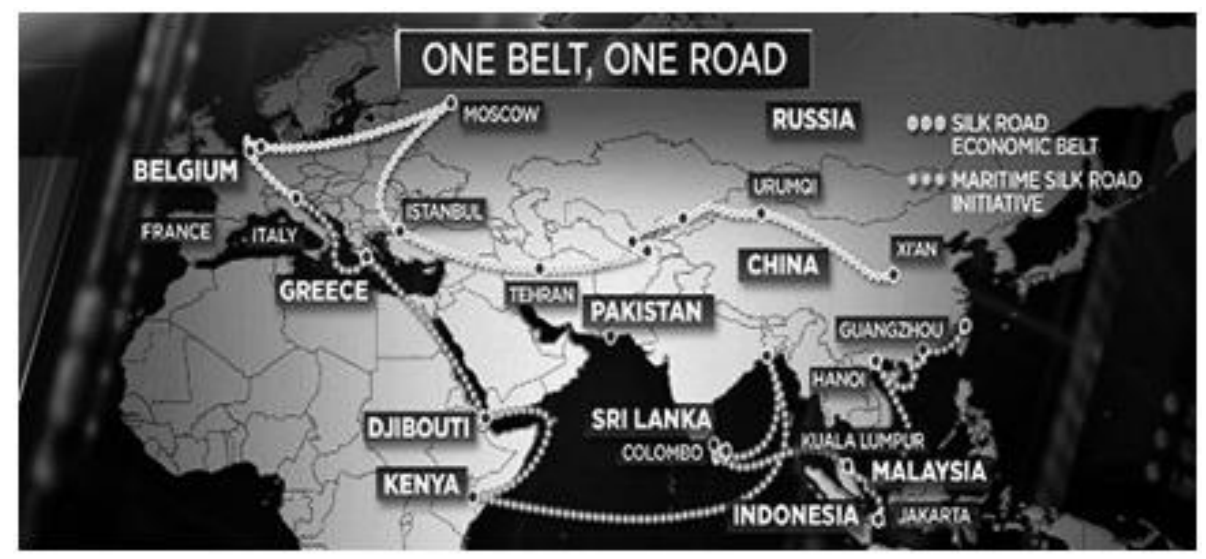

Source: BRI map by Chinese Government

CPEC provides an alternate route for China's imports of oil and gas from the gulf region, with Gwadar deep seaport located right at the mouth of Hormuz. It also provides an ideal location for a world class petrochemical complex. Going back to history, it's important to note that before Suez Canal was established, the sea trade ships between Asia and Europe had to go all the way from Atlantic Ocean down to the Cape of Good Hope and then upwards in the Indian Ocean. Suez Canal made the sea route between the two continents shorter, consequently increasing the trade volume significantly. Similarly, Gwadar will help to dramatically increase the trade volumes between the regional countries and is also 12 “Russia to become part of game changer CPEC," The Express Tribune, March 23, 2018,
https://tribune.com.pk/story/1667265/1-russia-become-part-game-changer-cpec. 
expected to supplement the Suez Canal in further cutting down the time and costs for good transportation between Asia, Africa and Europe.

CPEC has great potential in bringing down the quotient of hostility between Pakistan and its neighbours as it will also benefit Afghanistan and India enormously. It can provide an alternative vision to start a new chapter in regional cooperation. Natural routes of trade between Kabul and East Punjab as well as Kandahar and Rajasthan can be facilitated by CPEC. The South Asian region populated by over 1.7 billion people, half of whom live under poverty line (less than $2 \$$ per day), and whose potential has been held back by the regional proxy wars and conflicts can be unleashed, providing the much-needed economic upsurge in the region.

Pakistan being long standing strategic ally of China has special place in this whole initiative is injected with large investments for the CPEC, whereas Sri Lanka has leased out the Hambantota port project to China.

\subsection{American Response To CPEC}

As far as U.S is concerned, President George W. Bush was supportive of the Trans-Pacific Partnership (TPP), which was given final touches by President Obama to set rules for trade and investment in the Asia Pacific region ${ }^{13}$. That policy was reversed by Donald Trump as soon as he came into office. Had US stood by this agreement, it would have served its purpose better by supporting those countries, who want to be a part of OBOR and minimize their economic risks. US has also lost its influence to propose better terms of trade for countries, where China is the key exporter as it's too pre-occupied with the military actions and postcold war mentality and cannot present further a competitive and constructive investment plan to nations as opposite to BRI or TPP.

Russia on the other hand has returned as tremendous power in world politics. Although not as impactful as China in terms of economic prowess and goodwill among the poor nations, Russia

13 McBride, James, "What is the Trans-Pacific Partnership (TPP)," Council on Foreign Relations, May 15, 2018, https://www.cfr.org/backgrounder/what-trans-pacificpartnership-tpp.15th May 2018. on 20th September 2018 
has come up with strong policies under Vladimir Putin and smartly allied with China while the dragon rises to the to $p$ of the world. Russia has successfully signed agreements with individual states \& bilateral security pacts including agreements with countries sharing borders with Russia including Belarus and Armenia. Russia-Pakistan relations have also improved significantly over the past few years. Pakistan's offer to Russia to join CPEC and the positive response of Russians (Express Tribune, 2018), increased military ties between the two countries and Chinese apparent alliance with Russians to counter the US dollar's dominance in the monetary system of the world all point towards a convergence of interest between Pakistan, China and Russia, which will facilitate their joint efforts to boost strategic and economic ties in the future.

As China, Russia and other global players gaining ground, the influence of the US is stagnating. Facing aggressive moves by Moscow and Beijing, the U.S may be enforced to accept influence of exclusionary regional spheres. World order is in a transfor mative mode where Pakistan's bitter experience of US policies to wards it and devastating effects of its aggressive military actions and negative self-centred policies has pushed Pakistan towards China.

In regard to the Indian Ocean, Pakistan's interests to play effective role to ensure maritime security with the active assistance from its global and regional countries including China. The strong U.S and China military presence in the Indian Ocean needed to be monitored by concerned states. In this scenario, the fast development and increased Gwadar port operations may help for a better working relationship between Pakistan \& china in helping to secure sea routes. It has a huge potential of deflecting the external power's grouping within the region.

With the movement of world towards multi polar world, it is widely recognized by experts from the West and the East that the Indian Ocean region cannot be managed by one or two countries. The huge expanse of its area and the involvement of multiple players involving points out towards a collective responsibility of all stakeholders, with mutual respect and will to co-exist. This world cannot afford to have a war between nuclear armed states. 


\subsection{Fisheries \& Aquaculture}

Fisheries have found to be one of the key resources of Indian Ocean region and provides food to millions of people around the globe. About one billion people largely in developing countries depend on fish as their chief energy source of animal protein, FAO. In the year 2010, fish provided more than 2.9 billion people with about $20 \%$ of animal protein intake, and 4.3 billion people with $15 \%$ of fish protein ${ }^{14}$.U. $N$ agency reports shows that in some countries specifically small island countries, fish contributes around $25 \%$ of animal protein intake. Its major role in poverty alleviation and increased employment and business opportunities is vast. From annual production of 860,000 tons in 1950 to almost 11.5 million tons in 2010, fisheries sector has shown a phenomenal growth. It's expected that the demand is constant. A huge increase in fish production has been observed from 861,000 tons in 1950 to 11.5 million tons in 2010 and world total demand for fisheries products is expected to further rise from 50 million to $183 \mathrm{million}$ tons in the year 2015 with aquaculture activities predicted to $73 \%$ of this rise. Aquaculture offers vast potential for food provision and large number of livelihoods under the umbrella of Blue Economy will definitely add value in natural capital and its development while take care of ecological parameters during production activities and creating sustainable and decent employment opportunities and provides high quality goods for exports.

Natural fisheries resources have been facing the challenge of overexploitation due to growing public demand for seafood products. Therefore, there is a dire need to find balance between population demand \& environmental health for the promotion of sustainable fishing \& aquaculture. Sustainable fisheries can add value in billions and millions of tonnes of fish each year. While aquaculture has vast potential for continued growth to meet the food requirements at global level.

14 "The State of World Fisheries and Aquaculture - Opportunities \& Challenges," (2014) Accessed: 20th September 2018, http://www.fao.org/3/a-i3720e.pdf. ISSN- 


\subsection{Renewable Ocean Energy}

Rising awareness about the environmental degradation and global warming has resulted in an increased demand for renewable energy over the past two decades. Renewable sources of energy i.e., solar \& wind are already being employed worldwide. In this regard, the potential of $\mathrm{RE}$ in Indian Ocean's is tremendous. However, extra incentives in RE are in high demand to further reduce the fossil fuels burden. Now, time is appropriate to explore potential of $\mathrm{RE}$ sources obtained from the ocean. The ocean provides immense potential for blue RE from waves, tidal, wind, thermal, \& biomass energy sources.

In the above-mentioned actions, it can also be proposed to bring all the offshore oil \& gas communities together with the Renewable Ocean Energy community to carry out a gap analysis related to oil and gas exploration. In this scenario, the potential for offshore oil $\&$ gas sector development in the Indian Ocean region should also be considered.

\subsection{Offshore Hydrocarbons \& Sea-bed Minerals}

With the decline in inland mineral deposits and rising industrial demand, much attention has now been given on mineral exploration and seabed mining. The seabed covers minerals, which offer amazing economic development opportunities in both the EEZ of maritime nations and beyond the limits of national jurisdiction. Sea-bed exploration has already started in the Indian Ocean. However, major constraints in the commercialization of these resources face limited data availability of member states on resources of their Exclusive Economic Zones (EEZ), lack of exploration capacity, and mining \& processing of these mineral resources. Thus, authentic information is required to gain the maximum deployment of these marine minerals across the region.

\subsection{Marine Biotechnology}

Marine Biotechnology is a fascinating and growing new are of scientific research. It has the potential for building an ecosustainable and highly efficient society. Important areas of 
research in this field are relevant to aquaculture; whereby new methodologies can assist in breeding of selected species; increasing sustainable production; and improvement in animal welfare, which includes rise in food supply, use of zero waste recirculation systems, and preventive therapeutic measures.

The quality of aquaculture products needs to be improved to gain optimal nutritional components for human health. Another important sector of marine biotechnology is the development of Renewable Energy (RE) products and sustainable practises of biogas production from marine algae. Furthermore, sea is blessed with large amount of untapped minerals, which can be used potentially as novel drugs, nutraceuticals, and beauty care products. Blue Biotechnology can also be utilized in addressing major environmental issues including bio-sensing technologies for in-situ marine monitoring \& development of cost-effective and nontoxic antifouling technologies. Enzymes, Biopolymers, Bioluminescent materials can also be extracted through biotechnology, which can be used in many and important industrial processes.

\subsection{Coastal Tourism}

Indian Ocean has some of the most exotic coastal sites to visit. South Africa, Tanzania, Mauritius, Seychelles, Maldives, Sri Lanka, Indonesia, Thailand, and Malaysia etc. all have beaches and resorts that attract millions of tourists per year. Coastal tourism is a fast-growing sector contributing $10 \%$ of the world's GDP, creating 1 in 10 jobs globally. It has generated over US\$1.4 trillion in export earnings ${ }^{15}$. In view of this expected growth, it is critical that multiple arenas are explored to grow sustainable tourism.

As the world's largest country by population, China, is so close to Pakistani nation and its attachment with the CPEC project in particular and Pakistan in general ensures quite a substantial amount of tourism development not only in Pakistan's but al so in Iran's coastal areas. The China Outbound Tourism Research

${ }^{15}$ Rochelle Turner, "Travel \& Tourism: Economic Impact 2017 World," World Travel \& Tourism Council, accessed on September 21, 2018, https://www.wttc.org//media/files/reports/economic-impact-research/regions-2017/world2017.pdf. 
Institute (COTRI) shows that the Chinese overseas tours will raise from 145 million in 2017 to more than 400 million by the end of 2030 (Smith, 2018). According to UNWTO, out of the 600 million additional trips in world tourism bringing the total from 1.2 billion in the year 2017 to 1.8 billion by the end of 2030 , which is almost half of them, will originate in China ${ }^{16}$. The country will contribute a quarter of international tourism.

Moreover, with the Gwadar port development, the influx of traders and families from Central Asian Republics is also expected to grow phenomenally. Tourism expenditures, export \& import of tourism related products, and services generate hand some income to the economy of host country. Tourism is considered as a key source of foreign exchange earnings of about $38 \%$ of all countries. Government revenues from tourism sector can be characterize d as direct and indirect contributions. Direct contributions are generated by taxes on revenues from tourism businesses, touris $m$ employment, and through direct charges on tourists i.e., Eco-tax or departure taxes. Indirect contributions develop from taxes and duties on supply of goods and services to tourists including tax on souvenirs restaurants, etc.

According to the World Travel \& Tourism Council (2011) ${ }^{17}$ alone, travel \& tourism contributed $9 \%$ of the global GDP and provided 260 million jobs worldwide. Tourism can generate large number of jobs directly through restaurants, hotels, souvenir sales, taxis and indirectly through goods and supply services needed by tourism related businesses.

Tourism also has the power to induce local government to improve the infrastructure by modernizing water and sewage systems, roads, electricity, telephone and public transport networks. All this can improve the quality of life for residents as well as facilitate tourism.

16 Oliver Smith, "The unstoppable rise of the Chinese traveller - where are they going and what does it mean for over tourism?" The Telegraph, April 11, 2018.

17 "Travel \& Tourism Economic Impact 2017 World, World Travel \& Tourism Council, (March, 2017). 
In view of IORA's decision not to include Pakistan primarily because of Indian attempt to isolate Pakistan in the region ${ }^{18}$, Pakistan needs to pursue the goals of emerging blue economy concept in collaboration with its regional partners through platforms such as SCO, OIC and bilaterally with countries of the ASEAN. Having picturesque coastal areas in Baluchistan and Sindh, Pakistan also needs to upgrade its own strategy to develop coastal tourism, as CPEC will result in lots of tourists from China and regional countries visiting Pakistan. The potential is worth billions of dollars, but the pre-requisites of manpower training, world class infra-structure and entertainment facilities along with better law and order situation needs to be provided to harness the upcoming opportunities in this area.

\section{Conclusion and Recommendations}

The geo-politics and geo-economics of the Indian Ocean Region (IOR) littoral are interconnected to each-other due to large scale of population, trade \& cultural routes, sea-based economy, coastal tourism and other interests of leading global powers. IOR has tremendous potential of geo-economic activities which are not only important for the Asian countries but also equally important for the entire world. The addition of Belt and Road Initiative (BRI) has provided new avenues to harness the true potential and uplift the poverty by improving existing socio-economic ties in the Indian Ocean littoral countries. It is also important to notice that the geo political aspects have diverse dimensions in the region where philosophy of enhanced cooperation for peace and sustainability would be highly needed to promote socio-economic uplift and ensure prosperity in the region. The new economic initiative by the Chinese Government is promising for the entire region where Pakistan and Iran would be the major beneficiaries from overall development. The role of major global powers needs to promote peace and cooperation for which China, Pakistan and Iran need to make extra efforts on diplomatic fronts.

${ }^{18}$ Asif Ezdi, A. “The rise of the Indian Ocean Rim,” THE NEWS, June 15, 2015. 